\title{
The mining canon and the budget political cycle in Peru's district municipalities, 2002-2011
}

\author{
Carol Pebe, Norally Radas and Javier Torres
}

\begin{abstract}
This study seeks to determine whether access to a larger volume of funds from the mining canon affects the level of capital spending by district mayors in election years. The effect of Peru's electoral cycles on district public investment (from 2002 to 2011), and how this relates to the mining canon, is analysed in terms of the budget political cycle, using a fixed-effects panel model. The results show that the mining canon has a differential effect in the $20 \%$ of districts that receive the largest amounts; but, in general, there is no clear cyclicality between capital expenditure in these municipalities and election years.
\end{abstract}

\section{Keywords}

Mining, tax revenues, local government, municipal government, public expenditures, budget performance, political aspects, elections, Peru

JEL classification

D72, P16, H72, Q32, Q33

\section{Authors}

Carol Pebe Bernal holds a licenciado degree in Economics from the University of the Pacific of Peru. Email: carolpebe@gmail.com.

Norally Radas Kovalchuk holds a bachelor's degree in Economics from the University of the Pacific of Peru. Email: norallyfrk@gmail.com.

Javier Torres Gómez is a Professor in the Academic Department of Economics at the University of the Pacific of Peru. Email: j.torresgomez@up.edu.pe. 


\section{Introduction}

The share of the extractive sectors in the Peruvian economy grew from 9.3\% of gross domestic product (GDP) in 2004 to 13.2\% in 2012; and this has led to a significant increase in the tax revenue received by the different governmental entities through canon transfers (mining, hydropower, gas and others). ${ }^{1}$ Such transfers made to regional and local governments (municipalities) accounted for $23 \%$ of total transfers in 2004, and this percentage had grown to $43 \%$ by $2012 .^{2}$

The mining canon consists of $50 \%$ of the income tax revenue received by the State for the exploitation of mineral, metallic and non-metallic resources. The revenue thus obtained is distributed as follows: $10 \%$ of the total canon is allocated to the local governments of the district municipality or municipalities in which the natural resource in question is extracted; $25 \%$ is allocated to the local governments of the district and provincial municipalities in which the natural resource is extracted; $40 \%$ is allocated to the local governments of the respective department(s); and $25 \%$ is assigned to the corresponding regional governments; and, from that percentage, the latter are required to transfer $20 \%$ to the national universities in their jurisdiction.

Among the aforementioned entities, the main beneficiaries have been local governments, since they received a total of roughly S/. 6.5 billion under the canon to carry out public investment projects in 2012. These funds can be used to finance and co-finance public investment projects, including actions to provide public services and maintain infrastructure, medical clinics and hospitals, among other things. Regional and local governments can allocate up to $20 \%$ of these transfers to current expenditure, including the maintenance of public investment projects.

As a result, from 2002 to 2011 , the district municipalities' total expenditure grew by $290 \%$ (see annex A1), with the largest increase occurring in capital spending, which in 2011 was 7.3 times its 2002 level. This growth was particularly pronounced in 2006 and 2008, when capital expenditure increased by $77 \%$ and $70 \%$, respectively. Capital spending by the $20 \%$ of municipalities receiving the largest amounts through the canon increased by more than the average of other municipalities in most years of the period 2002-2011, particularly in 2006 (109\%) and 2008 (78\%).

In this context, it is important to analyse the influence of the political factor on the level of capital expenditure in the district municipalities and the timing of the execution of such expenditure. For example, a report by the Office of the Comptroller General of the Republic (2011) noted that the transfers made to some local governments had not resulted in improved service coverage and attention to the population's basic needs. As a possible explanation for this, the report mentioned misalignment between the political interests of the authorities and the long-term well-being of their localities. ${ }^{34}$

The capacity of local governments to effectively manage public investment is another problem that is present in Peruvian public management. Such capacity is limited not only by a dysfunctional budget planning and appropriation system, obstacles and constraints on the implementation of activities, and

1 The canon is the share in the income and rents obtained by the State from natural resource extraction, which accrue to the regional and local governments, and universities and higher public institutes, in whose jurisdictions the activities in question take place. The following canons exist: mining, hydropower, gas, fishing and forestry, along with the oil canon and its additional component (surcanon).

2 Regional and local governments (provinces and districts) also receive other transfers under the Municipal Compensation Fund (FONCOMUN), the Camisea Fund for Socioeconomic Development (FOCAM), regional trusts, the Glass of Milk Programme, donations and royalties, among others.

3 The report also states that some municipalities misused public resources or made improper payments. For this reason, in July 2012, the Office of the Comptroller General announced the launch of an audit, referred to as "Operativo Canon", to determine whether the funds obtained by local and regional governments from the extraction of natural resources had been used legally and effectively.

4 Other possible causes are: (i) inadequate definition of project priorities to be implemented within the framework of the rules governing the use of the canon; (ii) lack of strategic planning to assess their localities' unmet basic needs, such as water and sanitation, health or education; and (iii) the weak public management capacity of regional and local governments. 
poor coordination between public institutions and programmes; technical capacity constraints further compound this problem. Aragón and Casas (2009) found evidence that a lack of investment management capacity, in other words project management, accounting and finance, planning and coordination with other public entities, can undermine the capacity of local governments to increase public investment, even if they have financial resources available (Aragón and Casas, 2009). ${ }^{5}$

This study seeks to determine whether access to larger transfers through the mining canon creates an additional incentive for opportunistic expenditure execution by the district mayors. Districts with a larger volume of transfers would be more likely to increase the amount of capital spending in pre-election years.

The study focuses on the mining canon for three reasons: firstly, because of the importance of mining canon transfers in Peru, which represented $61 \%$ of all transfers under some type of canon in 2004-2012, with a rising trend over the last decade. ${ }^{6}$

Secondly, the exogenous nature of the canon means that the amount of funding transferred to each subnational government is determined by pre-established rules and ultimately depends on metal prices. This means that local authorities cannot directly influence the allocation of the funds in question. Previous studies have used the exogenous effect of increasing the canon to assess the impact of mining in different sectors of Peru's economy. Aragón and Rud (2013) used the case of a large-scale mine in a region of Peru (Cajamarca) to identify the existence of positive effects of mining activities on the living conditions of the local population, the main explanation being backward linkage. Gajate-Garrido (2013) analysed the effect of public spending on the nutritional status of children in Peru, using the unanticipated regional mining canon as an instrument to account for the endogenous nature of public spending. The results revealed a positive nutritional effect only for children in urban areas.

Thirdly, transfers in respect of the mining canon do not revert to the public treasury which is very important because it could create incentives to execute expenditure in the most convenient period.

The study focuses on district municipalities because they receive a large share of mining canon transfers (see annex A2). Moreover, the districts are the smallest administrative units of the State, and their actions affect the population directly. Lastly, district-level control and oversight can be complex, which would give mayors some discretion over their use of the funds.

The rest of this article is organized as follows: section II reviews the literature on the political budget cycle and natural resource abundance. Sections III and IV describe the data sources and methodology used, while section $\mathrm{V}$ analyses the results obtained. Lastly, section VI sets out the main conclusions.

\section{Literature review}

This section relates the literature on natural resource abundance to that on the political budget cycle.

\section{Resource abundance}

The effect of resource abundance was initially studied by Gelb and others (1988) and by Auty (1990), who empirically analysed the relationship between natural resource extraction (oil in particular) and economic growth. Nonetheless, it was the work of Sachs and Warner (1995, 1997 and 2001) that first recognized the robustness of the negative relationship and coined the expression "resource curse".

\footnotetext{
5 This effect is not considered in this study, however.

6 Although the 2008 financial crisis reduced the net earnings of the mining companies, these transfers recovered as from 2010, to reach a level of S/. 5,000 million in 2012.
} 
According to Sachs and Warner (2011), countries with abundant natural resources tend to have high price levels, which directly erodes the competitiveness of other export sectors; so countries lose the possibility of achieving export-led growth.

On the other hand, there is a vast literature demonstrating that the adverse effect of natural resource abundance can be explained by other factors, such as the level of human capital or the quality of public institutions. For example, Gylfason (2001) showed that the negative effect stems from less concern for education by the authorities in resource-rich countries, which implies a lower level of expenditure. In terms of public management, Manzano and Rigobon (2001) showed that the overindebtedness of natural-resource-rich countries is the real problem for growth. In addition, Hausmann and Rigobon (2002) analysed the structure of trade and showed that more diversified economies are less likely to suffer adverse effects from natural resources.

Thus, countries that consider natural capital as their greatest asset can develop a false sense of security and become negligent in managing those resources and accumulating human capital. By controlling for these effects through indirect variables and using other methods to measure natural resource abundance, Brunnscheweiler (2008) found a direct positive relationship between natural resources and economic growth in 1970-2000, but no significant results confirming a negative relation between resource abundance and institutional quality. Similarly, according to Bravo-Ortega and De Gregorio (2005), higher levels of education can offset the negative effects. Thus, on average, countries with high levels of human capital are likely to benefit from natural resources. In their estimation, the authors found a positive relationship between income level and natural resources. The explanations for the underdevelopment of countries with abundant natural resources come mainly from political science and economics. According to Isham and others (2005), from the political science standpoint, the two main effects proposed are the income effect and the anti-modernization effect. The first occurs when budget growth based on income from natural resource extraction affords government greater discretion and relaxes control by the population. Weaker control allows government spending to be used for purposes other than meeting the population's needs or to improve the economy's productivity. For example, Robinson, Torvik and Verdier (2005) noted that, by enhancing the value of holding power and providing politicians with larger tax revenues which they can use to influence the outcome of elections, natural-resource boom periods aggravate the misallocation of resources in the rest of the economy. Collier and Goderis (2007) claimed that natural resource rents stimulate unproductive lobbying and rentseeking, and encourage inefficient distribution in favour of political support. In contrast, there are fewer incentives for modernization, both for the government and for workers, because budget funding (and hence the financing of expenditure) comes from a specific extractive activity that requires specialized skills. As a result, most of the population is excluded from resource-related activity (although it maintains a passive benefit), which reduces incentives to increase productivity in other sectors and among workers generally.

In economics, the expression "Dutch disease" is used to explain the apparently contradictory result of resource wealth being associated with lower growth rates. The exploitation of natural resources alters the relative prices of other goods and services, which triggers an internal reallocation of capital and labour from tradable to extractive sectors, and fosters growth in non-tradable sectors (services). ${ }^{7}$ The specialization of the economy is efficient in the short run; but, when extraction of the resource declines (or it is completely depleted), the economy lacks other sectors that are sufficiently developed to maintain the previous production level or absorb new job-seekers.

Nonetheless, Collier (2010) noted that while the initial explanation was purely economic, the importance of political factors is increasingly clear. Deacon (2011) argued that a number of empirical

\footnotetext{
7 Isham and others (2005) also mention the entrenched inequality effect. This refers to the different development trajectories in former colonies (determined by the timing and nature of decolonization, property right regimes and the type of crops grown), which make it possible to explain the effects of natural resources on their economies today.
} 
patterns had motivated the study of interactions with political institutions; and it was found, in particular, that resource abundance is more likely to be a curse when: (i) governance and the rule of law are initially weak; and (ii) the resource is highly concentrated spatially.

\section{Political budget cycle}

The political budget cycle is defined as a periodic fluctuation of government fiscal policy induced by the cyclicality of elections (see Shi and Svensson (2001) for further information). Opportunistic behaviour by rulers is manifested through fiscal policy management (taxes, transfers and public spending) aimed at influencing voter preferences and increasing their chances of electoral triumph (Gámez and Ibarra-Yúnez, 2007).

The literature on the political budget cycle can be divided into two groups. One of them follows the theoretical model developed by Rogoff (1990), which focuses on the question of asymmetric information on politicians' levels of competency. Voters shape their voting expectations based on observable fiscal policy outcomes in that period. The basic assumption is that only the most competent mayors can increase expenditure (or observable expenditure) in a given period. In the pre-election year, these authorities increase spending to send a signal of competency to the electorate, so that it favours them in elections. ${ }^{8}$ Signalling thus gives rise to political budget cycles.

In contrast, the models of the second group focus on the ability of mayors to manage fiscal policy so as to bias voter preferences (Shi and Svensson, 2001). If greater provision of public goods (or increased capital expenditure) can be understood by the population as a sign of a higher level of competency, all politicians would have the same incentives to increase spending in pre-election periods. Unlike Rogoff's model, these models argue that all politicians have the same capacity to increase public spending, irrespective of their level of competency.

Apart from the models' different emphases on signalling competency or on the ability of spending to influence voter preferences, the chief conclusion is that public spending is affected by the electoral calendar. ${ }^{9}$

Initially, empirical studies focused on proving the existence of the political budget cycle at the country level. For example, Shi and Svensson (2006) examined the presence of this cycle in a sample of developing and developed countries, and found that the cycle existed in both types, but to a greater degree in the former.

Recently, the greater information available at the subnational level has been used to test the existence of the political budget cycle at the local level. Akhmedov, Ravichev and Zhuravskaya (2002) found evidence of short political cycles in the regions of Russia in 1996-2001. Drazen and Eslava (2005 and 2008) studied the political budget cycle in Colombian municipalities and found evidence that it influences a change in the composition of expenditure in pre-electoral periods. Gámez and Ibarra-Yúnez (2007) also found evidence of the existence of this cycle in state-level public expenditure in Mexico.

To analyse how the benefits obtained from extractive industries influence elections, Monteiro (2009) and Monteiro and Ferraz (2012) evaluated the impact of oil royalties received by municipalities in Brazil and concluded that they generate benefits for incumbent governments and reduce political competition, although the effect fades away over the medium term.

\footnotetext{
8 A mayor is considered "competent" if he/she needs less income to provide a certain level of public services.

9 Pre-electoral management cannot be viewed only as an increase in expenditure or generation of deficits. Drazen and Eslava (2005) argue that it occurs through changes in the composition of spending, with a larger amount of resources being allocated to the most influential voters through changes in fiscal policy or in the expenses that are most highly valued by the majority of voters.
} 
In Peru, Carranza, Chávez, and Valderrama (2006) studied the political economy of the national budget process and demonstrated the existence of political budget cycles in nonfinancial public spending during the Fujimori administration (1995-2000). Nonetheless, at the subnational level no evaluation has been made, either of the existence of the political budget cycle or of the effect of rents obtained from natural resource exploitation on the authorities' fiscal behaviour. The study that comes closest is that of Sanguinetti (2010), who analysed the effect of the canon on fiscal practices at the regional level. This author found that canon transfers alter the composition of spending and increase the relative importance of public investment. This result, however, is probably a consequence of the restrictions placed on the use of canon resources.

The present study is one of the few to analyse the cyclicality of the execution of Peruvian public spending at the district level and how this relates to the transfers received as a result of mineral extraction.

\section{Data sources}

The first part of the analysis is based on data from a balanced panel of 1,131 district municipalities for the period 2002-2011. ${ }^{10}$ The base contains budget data, such as capital expenditure executed, resources received through the mining canon, and the general budget of each district. ${ }^{11}$ The information comes from the Economic Transparency Portal of the Ministry of Economy and Finance, and is used in both absolute value (S/. million) and in per capita terms. To properly identify the effect of the canon, it was decided to subtract the budgeted amount of the mining canon from each district's budget, so that the general budget better reflects the availability of district resources. Lastly, given that political budget cycles have to be evaluated over a period spanning at least four years (the term of office in Peru), it is clear that the database covers two political cycles (2002-2006, 2006-2010 and 2011).

In addition to the budget data, control variables (demographic, labour and income) were incorporated, which could affect the level of capital expenditure. Thus, the projected population by district, the economically active proportion of the population by district, the departmental illiteracy rate, the rural proportion of the population by department, the dependency ratio by province, and the poverty level by department are all included. These data come from calculations and estimates made by the National Institute of Statistics and Informatics (INEI).

\section{Methodology}

To verify the existence of a political budget cycle and evaluate the effect of the canon on it, the study analyses following: capital expenditure as a function of economic and demographic variables, a set of dummy variables per year and the amount transferred through the mining canon. In particular, the following models are proposed:

$$
\begin{gathered}
G_{i, t}=\alpha_{i}+X_{i, t \square}^{\prime} \beta+\sum_{2002}^{2011} \gamma_{t} D_{t}+\delta_{1} \text { canon }_{i, t}+\sum_{t=06,10}^{\square} D_{t} \delta_{2 t} \text { canon }_{i, t \square}+\varepsilon_{i t} \\
G_{i, t}=\alpha_{i}+X_{i, t}^{\prime} \beta+\sum_{2002}^{2011} \gamma_{t} D_{t}+\delta_{1} \text { canon }_{i, t}+\sum_{t=06,10}^{\square}\left(\sum_{g=1}^{g=5} \delta_{2 g t} D_{t} D_{g}\right)+\varepsilon_{i t}
\end{gathered}
$$

\footnotetext{
10 Although the universe of Peruvian district municipalities in 2011 actually numbered 1,635, this study only considers those for which annual observations are available for the whole period analysed.

11 In the "budget" variable, the modified initial budget (MIP) is used, because this is what is actually received by the municipalities.
} 
$G_{i, t}$ is the capital expenditure per capita executed by district $i$ in year $t$. The variable $X_{i, t}$ groups together sociodemographic and economic controls (for example, the per capita municipal budget at the start of the period, the illiteracy rate and the rural proportion of the population). The sum of the dichotomous variables per year $\left(D_{t}\right)$ reveals the political cycle of spending.

Since a re-elected mayor has more experience in the management and execution of expenditure than one who has been elected for the first time, the number of years in office (reelec) is also controlled for.

The effect of the mining canon is identified with two variables. The variable cannon $_{i, t}$ reflects the direct effect of the amount of the transfer (per capita) on expenditure, while the interaction of the dummy variables in the electoral years and the amount of the canon $\left(D_{t} \delta_{2 t} c a n n o n_{i, t}\right)$ would identify the incremental effect on election spending.

There are two specifications. The first (1) incorporates the effect of the amount of the canon in a linear way, while the second (2) separates the districts into five groups $(g)$, according to the amount they receive under the canon, in an attempt to capture possible discontinuous effects. Both estimates use fixed effects by districts and robust standard errors. Thus, the effect of the canon would be identified from the changes occurring between the district municipalities over time.

\section{Empirical Estimation}

\section{Budgetary budget cycle}

Table 1 displays the basic results of the model in per capita terms; ${ }^{12}$ the effect of the budget (without considering canon transfers) is significant and positive - additional funds can be expected to increase spending capacity. Moreover, the mining canon variable has a positive and significant effect on capital expenditure. That is, the municipalities that have more resources available due to the mining canon usually execute greater capital expenditure.

The dummy variables that capture the effect per year are statistically significant, which suggests that capital expenditure is influenced by the execution period. It is also noted that the coefficients for 2006 and 2010 are higher than those of 2005 and 2009 in all specifications. Nonetheless, there is no clearly marked political cycle, since the coefficients estimated for the post-electoral years (2007 and 2011) are positive and higher than those estimated for years in which the elections were held.

Although several studies state that the political budget cycle should be observable in the preelection years (2005 and 2009), the municipal elections were held on the third Sunday of November of the year in which the municipal authorities' mandate expired. This means that the relevant year for analysing public expenditure is that in which the elections were actually held (2006 and 2010), since the incumbent authorities had nearly a whole year to organize expenditures so as to influence voter preferences. ${ }^{13}$

\footnotetext{
12 In the estimated model with variables measured in levels (which incorporates the size of the district population) there are no material differences.

${ }^{13}$ Although there are fiscal rules in place to limit expenditure increases in election years, the fact that they are not enforced means they do not act as a restraint on spending.
} 
Table 1

Political budget cycle

\begin{tabular}{|c|c|c|c|c|}
\hline & (1) & (2) & (3) & (4) \\
\hline \multirow[t]{2}{*}{ Literate population } & & & & -0.00124 \\
\hline & & & & $(0.000283)^{\star \star \star}$ \\
\hline \multirow[t]{2}{*}{ Rural population } & & & & 0.000378 \\
\hline & & & & $(0.000792)$ \\
\hline \multirow[t]{2}{*}{ Emergencies } & & & & $2.13 e-08$ \\
\hline & & & & $(2.05 e-07)$ \\
\hline \multirow[t]{2}{*}{ Re-election } & & & & $-2.17 e-06$ \\
\hline & & & & $(6.89 e-06)$ \\
\hline \multirow[t]{2}{*}{ Income (per capita) } & 0.154 & & 0.130 & 0.129 \\
\hline & $(0.0309)^{\star \star \star}$ & & $(0.0286)^{\star \star \star}$ & $(0.0287)^{\star \star \star}$ \\
\hline \multirow[t]{2}{*}{ Mining canon (per capita) } & 0.171 & & 0.170 & 0.170 \\
\hline & $(0.0423)^{\star \star \star}$ & & $(0.0382)^{\star \star \star}$ & $(0.0382)^{\star \star \star}$ \\
\hline \multirow[t]{2}{*}{2003} & & $1.81 \mathrm{e}-05$ & $1.13 \mathrm{e}-05$ & $4.12 \mathrm{e}-06$ \\
\hline & & $(3.32 \mathrm{e}-06)^{\star \star \star}$ & $(2.98 \mathrm{e}-06)^{\star \star \star}$ & (1.77e-05) \\
\hline \multirow[t]{2}{*}{2004} & & $6.97 e-05$ & $4.66 \mathrm{e}-05$ & $3.55 e-05$ \\
\hline & & $(3.95 e-06)^{\star \star \star}$ & $(6.04 \mathrm{e}-06)^{\star \star \star}$ & $(1.42 \mathrm{e}-05)^{\star \star}$ \\
\hline \multirow[t]{2}{*}{2005} & & $5.24 \mathrm{e}-05$ & $2.78 \mathrm{e}-05$ & $1.69 \mathrm{e}-05$ \\
\hline & & $(6.83 e-06)^{\star \star \star}$ & $(6.97 e-06)^{\star \star \star}$ & $(2.02 \mathrm{e}-05)$ \\
\hline \multirow[t]{2}{*}{2006} & & 0.000213 & 0.000167 & 0.000155 \\
\hline & & $(1.52 \mathrm{e}-05)^{\star \star \star}$ & $(1.45 e-05)^{\star \star \star}$ & $(3.51 e-05)^{\star \star \star}$ \\
\hline \multirow[t]{2}{*}{2007} & & 0.000300 & 0.000203 & 0.000170 \\
\hline & & $(1.90 \mathrm{e}-05)^{\star \star \star}$ & $(1.55 e-05)^{\star \star \star}$ & $(3.26 \mathrm{e}-05)^{\star \star \star}$ \\
\hline \multirow[t]{2}{*}{2008} & & 0.000507 & 0.000375 & 0.000341 \\
\hline & & $(2.88 \mathrm{e}-05)^{\star \star \star}$ & $(2.40 \mathrm{e}-05)^{\star \star *}$ & $(4.69 e-05)^{\star \star \star}$ \\
\hline \multirow[t]{2}{*}{2009} & & 0.000504 & 0.000296 & 0.000258 \\
\hline & & $(2.19 e-05)^{\star \star \star}$ & $(2.30 \mathrm{e}-05)^{\star \star \star}$ & $(4.54 \mathrm{e}-05)^{\star \star \star}$ \\
\hline \multirow[t]{2}{*}{2010} & & 0.000590 & 0.000396 & 0.000361 \\
\hline & & $(3.90 e-05)^{\star \star \star}$ & $(3.78 \mathrm{e}-05)^{\star \star \star}$ & $(8.12 \mathrm{e}-05)^{\star \star \star}$ \\
\hline \multirow[t]{2}{*}{2011} & & 0.000628 & 0.000437 & 0.000393 \\
\hline & & $(3.41 e-05)^{\star \star \star}$ & $(3.78 \mathrm{e}-05)^{\star \star \star}$ & $(7.38 \mathrm{e}-05)^{\star \star \star}$ \\
\hline \multirow[t]{2}{*}{ Constant } & 0.000270 & 0.000125 & $9.17 \mathrm{e}-05$ & 0.000113 \\
\hline & $(2.08 \mathrm{e}-05)^{* \star *}$ & $(1.43 e-05)^{\star \star \star}$ & $(9.30 \mathrm{e}-06)^{\star \star \star}$ & $(0.000334)$ \\
\hline No. of observations & 11310 & 11310 & 11310 & 11310 \\
\hline $\mathrm{R}^{2}$ & 0.377 & 0.161 & 0.448 & 0.449 \\
\hline
\end{tabular}

Source: Prepared by the authors.

Note: Robust standard errors shown in parentheses. *denotes significance at 10\%, ${ }^{* *}$ significance at $5 \%$ and ${ }^{* * *}$ significance at $1 \%$.

Figure 1 shows the trend of the estimated expenditure, using the coefficients in column 4 and the average of the control variables, while assuming that the variation in the expenditure comes exclusively from the year-effect. This shows that, in 2006 and 2010, capital expenditure rose by an average of $37.1 \%$ compared to the immediately preceding years (2005 and 2009 , respectively), with a much larger increase in 2006 than in 2010. ${ }^{14}$ Nonetheless, subsequent capital expenditure in 2007 and 2011 also increased by roughly $4.6 \%$.

\footnotetext{
14 There was also a significant increase in 2008.
} 
Figure 1

Predicted per capita capital expenditure deviation with respect to 2002 (Millions of soles)

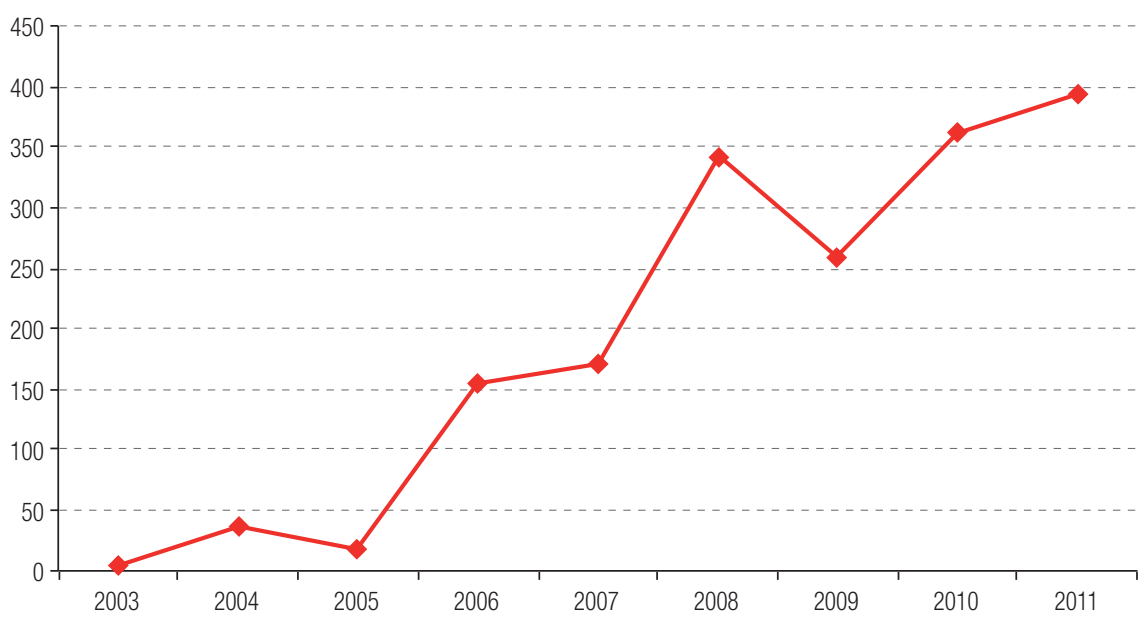

Source: Prepared by the authors, on the basis of data from the Ministry of Economy and Finance (MEF).

In terms of the control variables, a relatively larger illiterate population is significantly associated with a lower level of capital expenditure. The proportion of the population who suffer from illiteracy could proxy for local management capacity, which, being smaller, would also be reflected in a lower rate of expenditure execution. On the other hand, labour participation (percentage of the population who are economically active) displays a positive and significant coefficient. The relationship between capital expenditure and the proportion of people living in rural areas is negative but not significant. ${ }^{15}$ Similarly, neither the number of natural disasters nor the number of years in office appear to have significant effects on spending.

\section{Effect of the canon on the political budget cycle}

In order to determine whether access to the mining canon leads to higher capital expenditure in election years, multiplicative dummy variables were added to the foregoing model. In other words, the annual dummy variables were multiplied by the amount of the received through the canon in that period, so that the analysis focuses on the incremental effect of the mining canon in election years.

The results are reported in table 2 . The first column shows that the coefficients of the annual multiplicative dummies in the pre-election years (2005 and 2009) are not significant. From the second column onwards, the analysis focuses on the election years. In the second specification, the coefficient of the multiplicative dummy variable for both years is significant and positive, ${ }^{16}$ which would indicate that the mining canon has an incremental effect on capital expenditure in election years. The third specification also considers the years before and after the electoral period, to verify the robustness of the results. The effect is only significant for 2006 and loses all significance for 2010.

In the fourth and fifth columns the direct effect of the mining canon is eliminated and is incorporated through interactions with the annual dummy variables. The fourth column includes annual dummies for the years around the election, and the fifth column adds them for all years. The incremental effect of the canon is positive and, in this case, significant in both election years. Nonetheless, the coefficient of interaction for 2011 is even higher than that of 2010, although not significant.

\footnotetext{
15 The "poverty" variable is highly correlated with the rural population, for which reason it has not been included. In addition, data are only available at the district level until 2010.

${ }^{16}$ Although for 2010 it is only significant at a $90 \%$ confidence level.
} 
Table 2

Political budget cycle

\begin{tabular}{|c|c|c|c|c|c|}
\hline & (1) & (2) & (3) & (4) & $(5)$ \\
\hline \multirow[t]{2}{*}{ Literate population } & -0.00116 & -0.00116 & -0.00116 & -0.00108 & -0.00110 \\
\hline & $(0.000286)^{\star \star \star}$ & $(0.000286)^{\star \star \star *}$ & $(0.000276)^{\star \star \star}$ & $(0.000260)^{\star \star \star}$ & $(0.000259)^{\star \star \star}$ \\
\hline \multirow[t]{2}{*}{ Rural population } & 7.32e-05 & 0.000359 & $2.15 e-05$ & 0.000283 & 0.000232 \\
\hline & $(0.000694)$ & (0.000792) & $(0.000656)$ & $(0.000671)$ & $(0.000658)$ \\
\hline \multirow[t]{2}{*}{ Emergencies } & $9.20 \mathrm{e}-08$ & $5.81 \mathrm{e}-08$ & $1.41 \mathrm{e}-07$ & $9.32 \mathrm{e}-08$ & 8.07e-08 \\
\hline & $(1.89 \mathrm{e}-07)$ & $(2.01 e-07)$ & $(1.82 \mathrm{e}-07)$ & $(1.80 \mathrm{e}-07)$ & $(1.77 \mathrm{e}-07)$ \\
\hline \multirow[t]{2}{*}{ Re-election } & $-2.80 e-06$ & $-1.87 e-06$ & $-1.18 \mathrm{e}-06$ & $2.98 \mathrm{e}-07$ & $-4.22 \mathrm{e}-07$ \\
\hline & (7.09e-06) & $(6.76 e-06)$ & $(5.97 e-06)$ & $(6.03 e-06)$ & $(6.25 e-06)$ \\
\hline \multirow[t]{2}{*}{ Income (per capita) } & 0.140 & 0.134 & 0.139 & 0.200 & 0.193 \\
\hline & $(0.0212)^{\star \star \star}$ & $(0.0282)^{\star \star \star}$ & $(0.0240)^{\star \star \star}$ & $(0.0302)^{\star \star \star}$ & $(0.0303)^{\star \star \star}$ \\
\hline \multirow[t]{2}{*}{ Mining canon (per capita) } & 0.206 & 0.145 & 0.182 & & \\
\hline & $(0.0488)^{\star \star \star}$ & $(0.0375)^{\star \star \star}$ & $(0.0592)^{\star \star \star}$ & & \\
\hline \multirow[t]{2}{*}{2003} & $-9.23 e-07$ & $5.02 \mathrm{e}-06$ & $3.62 \mathrm{e}-06$ & $1.04 \mathrm{e}-05$ & $6.03 e-07$ \\
\hline & $(1.87 e-05)$ & $(1.75 e-05)$ & $(1.67 e-05)$ & $(1.72 \mathrm{e}-05)$ & $(1.85 e-05)$ \\
\hline \multirow[t]{2}{*}{2004} & $2.70 \mathrm{e}-05$ & $3.57 \mathrm{e}-05$ & $2.92 \mathrm{e}-05$ & $3.18 e-05$ & $2.44 \mathrm{e}-05$ \\
\hline & $(1.25 e-05)^{\star *}$ & $(1.46 \mathrm{e}-05)^{\star \star}$ & $(1.36 \mathrm{e}-05)^{\star \star}$ & $(1.53 e-05)^{\star *}$ & $(1.94 \mathrm{e}-05)$ \\
\hline \multirow[t]{2}{*}{2005} & $5.61 \mathrm{e}-06$ & $1.75 e-05$ & $3.04 \mathrm{e}-06$ & $6.32 \mathrm{e}-06$ & $1.75 e-06$ \\
\hline & $(1.78 \mathrm{e}-05)$ & $(2.08 \mathrm{e}-05)$ & $(1.69 \mathrm{e}-05)$ & (1.86e-05) & $(1.92 \mathrm{e}-05)$ \\
\hline \multirow[t]{2}{*}{2006} & 0.000140 & 0.000130 & 0.000115 & 0.000121 & 0.000115 \\
\hline & $(2.97 e-05)^{\star \star \star}$ & $(3.07 e-05)^{\star \star \star}$ & $(2.38 \mathrm{e}-05)^{\star \star \star}$ & $(2.45 e-05)^{\star \star \star}$ & $(2.47 e-05)^{\star \star \star}$ \\
\hline \multirow[t]{2}{*}{2007} & 0.000143 & 0.000179 & 0.000156 & 0.000187 & 0.000178 \\
\hline & $(2.94 \mathrm{e}-05)^{* * *}$ & $(3.60 e-05)^{* \star *}$ & $(3.02 e-05)^{\star \star *}$ & $(3.13 e-05)^{\star \star \star}$ & $(3.33 e-05)^{\star \star \star}$ \\
\hline \multirow[t]{2}{*}{2008} & 0.000311 & 0.000349 & 0.000319 & 0.000360 & 0.000321 \\
\hline & $(3.86 e-05)^{\star \star \star}$ & $(5.01 e-05)^{\star \star \star}$ & $(4.31 e-05)^{\star \star \star}$ & $(4.59 \mathrm{e}-05)^{\star \star \star}$ & $(4.29 e-05)^{\star \star \star}$ \\
\hline \multirow[t]{2}{*}{2009} & 0.000278 & 0.000267 & 0.000277 & 0.000288 & 0.000284 \\
\hline & $(5.49 e-05)^{* \star *}$ & $(4.95 e-05)^{\star \star *}$ & $(5.11 e-05)^{\star \star *}$ & $(5.14 \mathrm{e}-05)^{\star \star \star}$ & $(4.96 \mathrm{e}-05)^{\star \star \star}$ \\
\hline \multirow[t]{2}{*}{2010} & 0.000323 & 0.000334 & 0.000304 & 0.000305 & 0.000302 \\
\hline & $(6.69 e-05)^{\star \star \star}$ & $(7.08 \mathrm{e}-05)^{\star \star \star}$ & $(5.54 \mathrm{e}-05)^{\star \star \star}$ & $(6.18 \mathrm{e}-05)^{\star \star \star}$ & $(6.22 e-05)^{\star \star \star}$ \\
\hline \multirow[t]{2}{*}{2011} & 0.000351 & 0.000400 & 0.000333 & 0.000341 & 0.000332 \\
\hline & $(5.72 \mathrm{e}-05)^{\star \star \star}$ & $(7.80 \mathrm{e}-05)^{\star \star \star}$ & $(4.13 e-05)^{\star \star \star}$ & $(4.52 \mathrm{e}-05)^{\star \star \star}$ & $(4.55 e-05)^{\star \star \star}$ \\
\hline \multirow[t]{2}{*}{ Interaction: canon*2003 } & & & & & $6.92 \mathrm{e}-05$ \\
\hline & & & & & $(3.68 e-05)^{\star}$ \\
\hline \multirow[t]{2}{*}{ Interaction: canon*2004 } & & & & & $4.45 e-05$ \\
\hline & & & & & $(5.55 e-05)$ \\
\hline \multirow[t]{2}{*}{ Interaction: canon*2005 } & $2.98 \mathrm{e}-06$ & & $1.44 \mathrm{e}-05$ & $3.23 e-05$ & $4.52 \mathrm{e}-05$ \\
\hline & $(1.80 e-05)$ & & $(1.58 \mathrm{e}-05)$ & $(1.63 e-05)^{\star \star}$ & $(2.23 e-05)^{\star *}$ \\
\hline \multirow[t]{2}{*}{ Interaction: canon*2006 } & & $4.48 \mathrm{e}-05$ & $4.24 \mathrm{e}-05$ & $5.99 \mathrm{e}-05$ & 6.96e-05 \\
\hline & & $(1.18 \mathrm{e}-05)^{\star \star \star}$ & $(1.46 e-05)^{\star \star \star}$ & $(1.54 \mathrm{e}-05)^{\star \star \star}$ & $(1.91 e-05)^{\star \star \star}$ \\
\hline \multirow[t]{2}{*}{ Interaction: canon*2007 } & & & $-1.67 e-06$ & $1.62 \mathrm{e}-05$ & $2.00 \mathrm{e}-05$ \\
\hline & & & $(6.83 e-06)$ & $(7.43 e-06)^{\star \star}$ & $(9.61 e-06)^{\star \star}$ \\
\hline Interaction: canon*2008 & & & & & $2.17 \mathrm{e}-05$ \\
\hline & & & & & $(1.25 e-05)^{\star}$ \\
\hline Interaction: canon*2009 & $-2.35 e-05$ & & $-1.95 e-05$ & $-1.08 \mathrm{e}-05$ & $-8.01 e-06$ \\
\hline & $(1.50 \mathrm{e}-05)$ & & $(1.24 \mathrm{e}-05)$ & $(1.09 \mathrm{e}-05)$ & (9.11e-06) \\
\hline Interaction: canon*2010 & & $1.51 \mathrm{e}-05$ & $1.06 \mathrm{e}-05$ & $2.03 e-05$ & $2.31 \mathrm{e}-05$ \\
\hline & & $(8.85 e-06)^{\star}$ & (8.67e-06) & $(9.36 \mathrm{e}-06)^{\star \star}$ & $(1.10 \mathrm{e}-05)^{\star \star}$ \\
\hline Interaction: canon²011 & & & $1.36 \mathrm{e}-05$ & $2.31 \mathrm{e}-05$ & $2.80 \mathrm{e}-05$ \\
\hline & & & $(1.70 \mathrm{e}-05)$ & $(1.99 e-05)$ & $(2.13 e-05)$ \\
\hline Constant & 0.000236 & 0.000108 & 0.000252 & 0.000105 & 0.000137 \\
\hline & $(0.000289)$ & $(0.000337)$ & $(0.000274)$ & $(0.000281)$ & $(0.000277)$ \\
\hline No. of observations & 11310 & 11310 & 11310 & 11310 & 11310 \\
\hline $\mathrm{R}^{2}$ & 0.481 & 0.464 & 0.491 & 0.464 & 0.472 \\
\hline
\end{tabular}

Source: Prepared by the authors.

Note: Robust standard errors shown in parentheses. ${ }^{*}$ denotes significance at $10 \%$, ${ }^{* *}$ significance at $5 \%$ and ${ }^{* * *}$ significance at $1 \%$. 
The conclusion is that the receipt of mining canon transfers had an incremental effect on capital expenditure in 2006; but the effect is less noticeable in the 2010 electoral cycle. Thus, a per capita increase in mining canon transfers results in a smaller increase in capital expenditure per person in 2010 than in 2006.

\section{Categorization of municipalities according to the amount received under the mining canon}

As an alternative approach (see equation (2), in the methodology section), the municipalities were classified in quintiles according to the amount received under the mining canon in 2011. ${ }^{17}$ The transfers to the municipalities in the first group are between S/. 0 and S/. 7,000; those in the second group, between S/. 7,000 and S/. 98,000; those in the third group, between S/. 98,000 and S/. 466,000; those in the fourth group, between S/. 466,000 and S/. 1.549 million; and transfers to the fifth group exceed S/. 1.549 million. Each group consists of approximately 230 municipalities.

In addition, interactions with the annual dummy variables (since 2005) were created for all groups of municipalities: 24 interactions (6 binary variables per year for groups 2, 3, 4 and 5). This is done to evaluate whether capital expenditure is greater among municipalities that receive larger mining canon transfers. Table 3 presents the results.

In the first specification, the interactions of the pre-election years (2005 and 2009) are considered for all groups. The results are mixed: in 2005, the incremental effect is significant and negative for two groups of districts; in 2009, the effect is significant and positive for all groups except for the last one.

The second column considers the interactions in election years. In both electoral cycles (2006 and 2010) the incremental effect is positive and significant in the group 5 municipalities (which receive a larger amount under the canon). This means that the effect of canon transfers on capital expenditure is accentuated in election years by the $20 \%$ of municipalities that receive the largest transfers.

Apart from group 5, only group 4 reports positive coefficients in both electoral cycles; in the other groups the sign is negative. These results would support the hypothesis of the existence of a political budget cycle in municipalities that receive larger amounts through the mining canon.

To ensure the robustness of the results, the third specification included multiplicative variables in the years before and after the elections. This specification confirms that the incremental effect in the electoral year is positive and significant, but only for the group that receives the largest canon transfers in both elections, and for group 4 in the 2010 election.

\footnotetext{
${ }^{17}$ Although the total number of districts in 2011 was used in this classification, this does not differ significantly from the 1,131 districts considered for that year in subsequent analyses.
} 
Table 3

Political budget cycle with incremental effect of the canon

\begin{tabular}{|c|c|c|c|c|}
\hline & $(1)$ & (2) & (3) & (4) \\
\hline \multirow[t]{2}{*}{ Literate population } & -0.00109 & -0.00116 & -0.00106 & -0.000959 \\
\hline & $(0.000292)^{\star \star \star}$ & $(0.000290)^{\star \star \star}$ & $(0.000294)^{\star \star \star}$ & $(0.000267)^{\star \star \star}$ \\
\hline \multirow[t]{2}{*}{ Rural population } & 0.000157 & 0.000375 & 0.000237 & 0.000566 \\
\hline & $(0.000775)$ & $(0.000800)$ & $(0.000796)$ & $(0.000902)$ \\
\hline \multirow[t]{2}{*}{ Emergencies } & $1.84 \mathrm{e}-08$ & $6.63 e-08$ & $4.04 \mathrm{e}-08$ & $2.67 \mathrm{e}-08$ \\
\hline & $(2.06 e-07)$ & $(1.94 \mathrm{e}-07)$ & $(1.75 e-07)$ & $(1.78 \mathrm{e}-07)$ \\
\hline \multirow[t]{2}{*}{ Re-election } & $-2.24 \mathrm{e}-06$ & $-2.30 e-06$ & $-2.95 e-06$ & $-1.61 e-06$ \\
\hline & $(6.96 e-06)$ & $(6.84 e-06)$ & $(6.89 e-06)$ & $(6.59 e-06)$ \\
\hline \multirow[t]{2}{*}{ Income (per capita) } & 0.130 & 0.128 & 0.130 & 0.197 \\
\hline & $(0.0283)^{\star \star \star}$ & $(0.0289)^{\star \star \star}$ & $(0.0289)^{\star \star \star}$ & $(0.0276)^{\star \star \star}$ \\
\hline \multirow[t]{2}{*}{ Mining canon (per capita) } & 0.171 & 0.169 & 0.167 & \\
\hline & $(0.0383)^{\star \star \star}$ & $(0.0378)^{\star \star \star}$ & $(0.0381)^{\star \star \star}$ & \\
\hline \multirow[t]{2}{*}{2003} & $2.73 e-06$ & $3.73 e-06$ & $1.17 \mathrm{e}-06$ & $7.41 e-06$ \\
\hline & $(1.79 e-05)$ & $(1.75 e-05)$ & $(1.76 e-05)$ & $(1.68 \mathrm{e}-05)$ \\
\hline \multirow[t]{2}{*}{2004} & $3.36 \mathrm{e}-05$ & $3.54 \mathrm{e}-05$ & $3.33 e-05$ & $3.48 e-05$ \\
\hline & $(1.41 \mathrm{e}-05)^{\star \star}$ & $(1.40 \mathrm{e}-05)^{\star \star}$ & $(1.37 \mathrm{e}-05)^{\star \star}$ & $(1.56 \mathrm{e}-05)^{\star \star}$ \\
\hline \multirow[t]{2}{*}{2005} & $4.20 \mathrm{e}-05$ & $1.71 \mathrm{e}-05$ & $3.32 \mathrm{e}-05$ & $4.57 e-05$ \\
\hline & $(2.73 e-05)$ & $(2.02 \mathrm{e}-05)$ & $(2.26 e-05)$ & $(2.63 e-05)^{*}$ \\
\hline \multirow{2}{*}{2006} & 0.000151 & 0.000141 & 0.000137 & 0.000149 \\
\hline & $(3.48 \mathrm{e}-05)^{\star \star \star}$ & $(3.38 \mathrm{e}-05)^{\star \star \star}$ & $(3.34 \mathrm{e}-05)^{\star \star \star}$ & $(3.79 \mathrm{e}-05)^{\star \star \star}$ \\
\hline \multirow[t]{2}{*}{2007} & 0.000166 & 0.000172 & 0.000135 & 0.000153 \\
\hline & $(3.24 \mathrm{e}-05)^{* \star *}$ & $(3.28 \mathrm{e}-05)^{\star \star \star}$ & $(3.36 e-05)^{\star \star *}$ & $(3.96 e-05)^{\star * *}$ \\
\hline \multirow[t]{2}{*}{2008} & 0.000337 & 0.000345 & 0.000342 & 0.000378 \\
\hline & $(4.66 e-05)^{\star \star \star}$ & $(4.75 e-05)^{\star \star \star}$ & $(4.74 \mathrm{e}-05)^{\star \star \star}$ & $(5.70 e-05)^{\star \star \star}$ \\
\hline \multirow[t]{2}{*}{2009} & 0.000206 & 0.000263 & 0.000202 & 0.000211 \\
\hline & $(5.88 \mathrm{e}-05)^{\star \star \star}$ & $(4.63 e-05)^{\star \star \star}$ & $(5.67 e-05)^{\star \star \star}$ & $(6.48 \mathrm{e}-05)^{\star \star \star}$ \\
\hline \multirow[t]{2}{*}{2010} & 0.000355 & 0.000277 & 0.000271 & 0.000276 \\
\hline & $(8.06 \mathrm{e}-05)^{\star \star \star}$ & $(7.18 \mathrm{e}-05)^{\star \star \star}$ & $(7.18 \mathrm{e}-05)^{\star \star \star}$ & $(8.05 e-05)^{\star \star \star}$ \\
\hline \multirow[t]{2}{*}{2011} & 0.000386 & 0.000398 & 0.000450 & 0.000460 \\
\hline & $(7.28 \mathrm{e}-05)^{\star \star \star}$ & $(7.45 e-05)^{\star \star \star}$ & $(6.74 \mathrm{e}-05)^{\star \star \star}$ & $(7.82 \mathrm{e}-05)^{\star \star \star}$ \\
\hline \multirow[t]{2}{*}{ Interaction: g2*2005 } & $3.84 \mathrm{e}-06$ & & $-9.45 e-06$ & $-1.04 \mathrm{e}-05$ \\
\hline & $(1.57 e-05)$ & & $(1.23 e-05)$ & $(1.18 \mathrm{e}-05)$ \\
\hline \multirow[t]{2}{*}{ Interaction: g2²006 } & & $-1.23 e-05$ & $-1.55 e-05$ & $-1.65 e-05$ \\
\hline & & $(1.52 \mathrm{e}-05)$ & $(1.70 e-05)$ & $(1.62 \mathrm{e}-05)$ \\
\hline \multirow[t]{2}{*}{ Interaction: g2²007 } & & & $-1.73 e-05$ & $-1.17 e-05$ \\
\hline & & & $(1.72 \mathrm{e}-05)$ & (1.68e-05) \\
\hline \multirow[t]{2}{*}{ Interaction: g2*2009 } & $9.41 e-05$ & & $8.06 \mathrm{e}-05$ & $7.90 \mathrm{e}-05$ \\
\hline & $(3.06 e-05)^{\star \star \star}$ & & $(3.26 e-05)^{\star \star}$ & $(3.22 e-05)^{\star *}$ \\
\hline \multirow[t]{2}{*}{ Interaction: g2*2010 } & & $-5.20 e-06$ & $-5.48 e-06$ & $-1.42 \mathrm{e}-05$ \\
\hline & & (3.80e-05) & $(4.01 \mathrm{e}-05)$ & (3.80e-05) \\
\hline Interaction: g2*2011 & & & $-6.82 e-05$ & $-7.44 \mathrm{e}-05$ \\
\hline & & & $(4.66 e-05)$ & $(4.58 e-05)$ \\
\hline Interaction: g3*2005 & $-2.82 e-05$ & & $-1.88 \mathrm{e}-05$ & $-2.49 e-05$ \\
\hline & $(1.54 \mathrm{e}-05)^{\star}$ & & $(1.24 \mathrm{e}-05)$ & $(1.21 \mathrm{e}-05)^{\star *}$ \\
\hline Interaction: g3²006 & & $-1.43 e-05$ & $4.68 \mathrm{e}-06$ & $1.20 \mathrm{e}-06$ \\
\hline & & $(1.51 \mathrm{e}-05)$ & $(1.64 \mathrm{e}-05)$ & $(1.54 \mathrm{e}-05)$ \\
\hline Interaction: g3*2007 & & & $4.39 \mathrm{e}-05$ & $6.13 e-05$ \\
\hline & & & $(2.10 \mathrm{e}-05)^{\star \star}$ & $(2.12 \mathrm{e}-05)^{\star \star \star}$ \\
\hline Interaction: g3²009 & 0.000132 & & 0.000142 & 0.000138 \\
\hline & $(2.75 e-05)^{\star \star \star}$ & & $(2.99 e-05)^{\star \star \star}$ & $(2.91 \mathrm{e}-05)^{\star \star \star}$ \\
\hline Interaction: g3*2010 & & $1.02 \mathrm{e}-05$ & $3.20 \mathrm{e}-05$ & $2.27 e-05$ \\
\hline & & $(3.74 \mathrm{e}-05)$ & $(3.93 e-05)$ & $(3.74 e-05)$ \\
\hline
\end{tabular}


Table 3 (concluded)

\begin{tabular}{|c|c|c|c|c|}
\hline & (1) & (2) & (3) & (4) \\
\hline \multirow[t]{2}{*}{ Interaction: g3*2011 } & & & $-3.10 e-06$ & $-1.15 e-05$ \\
\hline & & & $(4.54 \mathrm{e}-05)$ & $(4.43 e-05)$ \\
\hline \multirow[t]{2}{*}{ Interaction: g4*2005 } & $-1.24 e-05$ & & $-9.64 e-06$ & $-1.73 e-05$ \\
\hline & $(1.61 e-05)$ & & $(1.38 \mathrm{e}-05)$ & $(1.36 e-05)$ \\
\hline \multirow[t]{2}{*}{ Interaction: g4²006 } & & $1.49 \mathrm{e}-06$ & $2.78 \mathrm{e}-06$ & $5.43 e-06$ \\
\hline & & $(1.47 e-05)$ & $(1.52 \mathrm{e}-05)$ & (1.46e-05) \\
\hline \multirow[t]{2}{*}{ Interaction: g4*2007 } & & & $4.25 e-05$ & $8.07 e-05$ \\
\hline & & & $(2.31 e-05)^{\star}$ & $(2.32 \mathrm{e}-05)^{* \star *}$ \\
\hline \multirow[t]{2}{*}{ Interaction: g4*2009 } & $8.46 e-05$ & & $8.90 \mathrm{e}-05$ & $9.31 e-05$ \\
\hline & $(3.25 e-05)^{\star \star *}$ & & $(3.54 \mathrm{e}-05)^{\star \star}$ & $(3.48 \mathrm{e}-05)^{\star \star \star}$ \\
\hline \multirow[t]{2}{*}{ Interaction: g4*2010 } & & $8.76 e-05$ & $9.04 \mathrm{e}-05$ & $9.51 e-05$ \\
\hline & & $(3.61 e-05)^{\star \star}$ & $(3.90 \mathrm{e}-05)^{\star \star}$ & $(3.72 \mathrm{e}-05)^{\star \star}$ \\
\hline \multirow[t]{2}{*}{ Interaction: g4*2011 } & & & -0.000107 & -0.000104 \\
\hline & & & $(4.70 \mathrm{e}-05)^{\star \star}$ & $(4.56 e-05)^{\star \star}$ \\
\hline \multirow[t]{2}{*}{ Interaction: g5²005 } & -0.000103 & & $-5.21 e-05$ & $-6.15 e-05$ \\
\hline & $(3.13 e-05)^{\star \star \star}$ & & $(2.05 e-05)^{\star \star}$ & $(2.19 e-05)^{* \star \star}$ \\
\hline \multirow[t]{2}{*}{ Interaction: g5²006 } & & 0.000102 & $9.12 \mathrm{e}-05$ & 0.000111 \\
\hline & & $(3.32 \mathrm{e}-05)^{\star \star \star}$ & $(3.76 e-05)^{\star \star}$ & $(3.93 e-05)^{\star \star \star}$ \\
\hline \multirow[t]{2}{*}{ Interaction: g5²007 } & & & 0.000105 & 0.000254 \\
\hline & & & $(3.90 e-05)^{\star \star \star}$ & $(4.68 \mathrm{e}-05)^{\star \star \star}$ \\
\hline \multirow[t]{2}{*}{ Interaction: g5²009 } & $-7.62 \mathrm{e}-05$ & & $-1.93 e-05$ & $5.25 e-05$ \\
\hline & $(0.000112)$ & & $(9.25 e-05)$ & $(7.35 e-05)$ \\
\hline \multirow[t]{2}{*}{ Interaction: g5²010 } & & 0.000356 & 0.000345 & 0.000405 \\
\hline & & $(9.52 \mathrm{e}-05)^{\star \star \star}$ & $(0.000101)^{\star \star \star}$ & $(0.000107)^{\star \star \star}$ \\
\hline \multirow[t]{2}{*}{ Interaction: g5²011 } & & & -0.000117 & $-5.71 e-05$ \\
\hline & & & $(0.000104)$ & $(0.000114)$ \\
\hline \multirow[t]{2}{*}{ Constant } & 0.000190 & 0.000103 & 0.000152 & $-3.00 e-05$ \\
\hline & $(0.000328)$ & $(0.000338)$ & $(0.000338)$ & $(0.000388)$ \\
\hline No. of observations & 11310 & 11310 & 11310 & 11310 \\
\hline $\mathrm{R}^{*}$ & 0.450 & 0.454 & 0.456 & 0.423 \\
\hline
\end{tabular}

Source: Prepared by the authors.

Note: Robust standard errors shown in parentheses. *denotes significance at $10 \%$, ${ }^{* *}$ significance at $5 \%$ and ${ }^{* *}$ significance at $1 \%$.

\section{Conclusions}

This study evaluates the importance of the political budget cycle and its interaction with the mining canon in the execution of capital expenditure in Peru's district municipalities. This is one of the few studies to analyse the cyclicality of the execution of public expenditure at the subnational level, and how this relates to the transfers received as a result of the extraction of mineral resources in Peru.

The first results show that, in general, there is no clear cyclicality between the capital expenditure of the municipalities and election years. Estimates of dummy variables per year show that on average, in 2006 and 2010 (capital expenditure increased by 37.1\% over the previous year (2005 and 2009, respectively); and there was also a post-election rise of about 4.6\% (in 2007 and 2011). Moreover, the amounts transferred through the mining canon had a positive and significant effect on capital expenditure in 2006. Yet, on average, its effect on the political budget cycle is marginal. Thus, a per capita increase in mining canon transfers results in a smaller increase in capital expenditure per person in 2010 than in 2006. 
Segregating the municipalities according to the amount received through the canon shows that only the group receiving the largest amount undertakes significant additional capital expenditure in the two election years. In other words, capital expenditure increases significantly in election years only in the group that receives the largest transfers under the mining canon.

\section{Bibliography}

Akhmedov, A., A. Ravichev and E. Zhuravskaya (2002), "Opportunistic Political Cycles: Test in a Young Democracy Setting" [online] http://pdc.ceu.hu/archive/00001617/.

Aragón, F. and C. Casas (2009), "Capacidades técnicas y gasto local: el caso de las municipalidades peruanas", Perspectivas. Análisis de temas críticos para el desarrollo sostenible, vol. 7, No. 1, Andean Development Corporation.

Aragón, F. and J. P. Rud (2013), "Natural resources and local communities: evidence from a Peruvian gold mine", American Economic Journal: Economic Policy, vol. 5, No. 2, Nashville, Tennessee, American Economic Association.

(2009), "¿Éxito en la sostenibilidad fiscal? El caso de Perú", Who Decides the Budget? A Political Economy Analysis of the Budget Process in Latin America, E. Stein, M. Hallerberg and C. Scartascini (eds.), Washington, D.C., Inter-American Development Bank (IDB).

Auty, R. (1990), Resource-based Industrialization: Sowing the Oil in Eight Developing Countries, New York, Oxford University Press.

Bravo-Ortega, C. and J. de Gregorio (2005), "The relative richness of the poor? Natural resources, human capital, and economic growth", Policy Research Working Paper, No. 3484, Washington, D.C., World Bank.

Brunnschweiler, C. (2008), "Cursing the blessings? Natural resource abundance, institutions and economic growth", World Development, vol. 36, No. 3, Amsterdam, Elsevier.

Carranza, L., J. Chávez and J. Valderrama (2006), La economía política del proceso presupuestario: el caso peruano, Washington, D.C., Inter-American Developmet Bank.

Collier, P. (2010), "The political economy of natural resources", Social Research, vol. 77, No. 4.

Collier, P. and B. Goderis (2007), "Commodity prices, growth, and the natural resource curse: reconciling a conundrum", Working Paper, No. 2007-15, University of Oxford.

Comptroller-General of the Republic (2011), Distribución y utilización de los recursos del canon, sobrecanon, fondo de desarrollo socioeconómico del proyecto Camisea y regalía minera en el Perú, Lima.

Deacon, R. T. (2011), "The political economy of the natural resource curse: a survey of theory and evidence", Foundations and Trends in Microeconomics, vol. 7, No. 2.

Drazen, A. and M. Eslava (2008), "Electoral manipulation via voter-friendly spending: theory and evidence", draft. (2005), "Electoral manipulation via expenditure composition: theory and evidence", NBER Working Paper, No. 11085, Cambridge, Massachusetts, National Bureau of Economic Research (NBER).

Gajate-Garrido, G. (2013), "Excluding the rural population: the impact of public expenditure on child malnutrition in Peru", Policy Research Working Paper, No. 6666, Washington, D.C., World Bank.

Gámez, C. and A. Ibarra-Yúnez (2007), "El ciclo político oportunista y el gasto de los estados mexicanos", Gestión y Política Pública, vol. 18, No. 1, Mexico City, Economic Research and Teaching Centre.

Gelb, A. and others (1988), Oil Windfalls: Blessing or Curse, New York, Oxford University Press.

Gylfason, T. (2001), "Natural resources, education and economic development", European Economic Review, vol. 45, No. 4-6, Amsterdam, Elsevier.

Hausmann, R. and R. Rigobon (2002), "An alternative interpretation of the 'resource curse': theory and policy implications", NBER Working Paper, No. 9424, Cambridge, Massachusetts, National Bureau of Economic Research.

Isham, J. and others (2005), "The varieties of resource experience: natural resource export structures and the political economy of economic growth", World Bank Economic Review, vol. 19, No. 2, Washington, D.C., World Bank.

Manzano, O. and R. Rigobon (2001), "Resource curse or debt overhang?", NBER Working Paper, No. 8390, Cambridge, Massachusetts, NBER National Bureau of Economic Research.

Monteiro, J. (2009), "Resource booms and politics: the effects of oil shocks on public goods and elections" [online] http://www.caf.com/attach/19/default/oil_politics_caf.pdf. 
Monteiro, J. and C. Ferraz (2012), "Does Oil Make Leaders Unaccountable? Evidence from Brazil's offshore oil boom" [online] http://www.unamur.be/en/eco/eeco/pdf/OilPaper2012-05.pdf.

Robinson, J. A., R. Torvik and T. Verdier (2005), "Political foundations of the resource curse", Norwegian University of Science and Technology [online] http://www.svt.ntnu.no/iso/ragnar.torvik/bardhanjde.pdf.

Rogoff, K. (1990), "Equilibrium political budget cycles", American Economic Review, vol. 80, No. 1, Nashville, Tennessee, American Economic Association.

Rogoff, K. and A. Sibert (1988), "Elections and macroeconomic policy cycles", The Review of Economic Studies, vol. 55, No. 1, Oxford University Press.

Sachs, J. and A. Warner (2001), "The curse of natural resources", European Economic Review, vol. 45, No. 4-6, Amsterdam, Elsevier.

(1997), "Natural Resource Abundance and Economic Growth", Cambridge, Massachusetts, Harvard University [online] http://citeseerx.ist.psu.edu/viewdoc/download?doi=10.1.1.422.8285\&rep=rep1\&type=pdf. (1995), "Natural resource abundance and economic growth", NBER Working Paper, No. 5398, Cambridge, Massachusetts, National Bureau of Economic Research (NBER).

Sanguinetti, P. (2010), "Canon minero y decisiones fiscales subnacionales en el Perú", Working Papers, No. 2010/01 [online] https://www.caf.com/media/3180/201001SanguinettiFebrero2010.pdf.

Shi, M. and J. Svensson (2006), "Political budget cycles: do they differ across countries and why?", Journal of Public Economics, vol. 90, No. 8-9, Amsterdam, Elsevier.

_ (2001), "Conditional political budget cycles", CEPR Discussion Paper, No. 3352 [online] http://people. su.se/ jsven/pbc.pdf. 


\section{Annex A1}

Table A1.1

District municipality categories according to the amount received under the mining canon in 2011

(Soles)

\begin{tabular}{llrrr}
\hline Category & & & & \\
\hline 1 & from & 0 & to & 7000 \\
\hline 2 & from & 7000 & to & 98000 \\
\hline 3 & from & 98000 & to & 466000 \\
\hline 4 & from & 466000 & to & 1549000 \\
\hline 5 & from & 1549000 & to & more \\
\hline
\end{tabular}

Source: Prepared by the authors.

Note: The classification by quintiles was based on the total number of districts according to the amount received under the canon in 2011.

Figure A1.1

Trend of capital expenditure executed by the district municipalities in each category (2002-2011)

(Billions of soles)

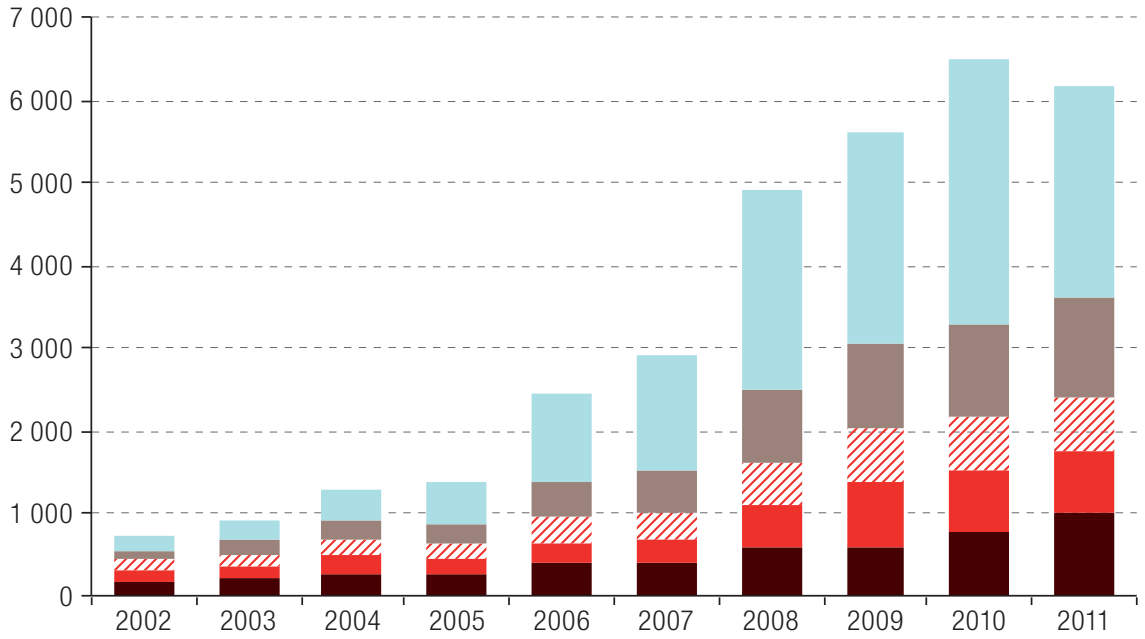

-Group 1 Group 2 \%, Group 3 Group 4 Group 5

Source: Prepared by the authors, based on data from the Ministry of Economy and Finance (MEF).

Note: The classification by quintiles was based on the total number of districts according to the amount received under the canon in 2011.

Table A1.2

Trend of capital expenditure growth in the district municipalities by canon group (Percentages)

\begin{tabular}{lrrrrrrrrr}
\hline Annual growth & 2003 & 2004 & 2005 & 2006 & 2007 & 2008 & 2009 & 2010 & 2011 \\
\hline Group 1 & 34 & 21 & -3 & 62 & -1 & 55 & 1 & 28 & 28 \\
\hline Group 2 & 10 & 37 & -17 & 34 & 16 & 73 & 48 & -3 & 4 \\
\hline Group 3 & 9 & 52 & -7 & 62 & 8 & 63 & 25 & 0 & 4 \\
\hline Group 4 & 15 & 56 & 9 & 71 & 19 & 60 & 21 & 9 & 4 \\
\hline Group 5 & 34 & 55 & 36 & 109 & 28 & 78 & 4 & 27 & -20 \\
\hline Total & 21 & 43 & 8 & 77 & 18 & 70 & 13 & 17 & -5 \\
\hline
\end{tabular}

Source: Prepared by the authors.

Note: The classification by quintiles was based on the total number of districts according to the amount received under the canon in 2011. 


\section{Annex A2}

Table A2.1

Methodology used to distribute the mining canon

\begin{tabular}{llll}
\hline & Percentage & Recipient & Distribution criterion \\
\hline $\begin{array}{lll}\text { Mining canon } \\
\begin{array}{l}\text { (50\% of the income } \\
\text { tax levied on the } \\
\text { mining companies) }\end{array}\end{array}$ & $\begin{array}{l}\text { District municipalities in which } \\
\text { the resources are extracted }\end{array}$ & $\begin{array}{l}\text { If there is more than one municipality, } \\
\text { it will be distributed in equal parts. }\end{array}$ \\
\cline { 2 - 4 } & $\begin{array}{l}\text { District municipalities of the province in } \\
\text { which the resources are extracted }\end{array}$ & $\begin{array}{l}\text { According to population and } \\
\text { unmet basic needs. }\end{array}$ \\
\hline $5 \%$ & $\begin{array}{l}\text { Provincial municipalities in the department } \\
\text { where the resources are extracted }\end{array}$ & $\begin{array}{l}\text { According to population and } \\
\text { unmet basic needs. }\end{array}$ \\
\hline
\end{tabular}

Source: Prepared by the authors, based on data from the Ministry of Economy and Finance (MEF), Metodología de distribución. 


\section{Annex A3}

Table A3.1

Description of the political budget cycle sample variables

\begin{tabular}{|c|c|c|c|c|c|c|}
\hline Variable & Districts & Years & Mean & $\begin{array}{l}\text { Standard } \\
\text { deviation }\end{array}$ & Minimum & Maximum \\
\hline Departmental illiteracy rate & 1131 & 10 & 0.1211 & 0.0603 & 0.0228 & 0.2790 \\
\hline $\begin{array}{l}\text { Proportion of rural } \\
\text { departmental population }\end{array}$ & 1131 & 10 & 0.4161 & 0.2241 & 0.0000 & 0.8368 \\
\hline $\begin{array}{l}\text { Number of emergencies } \\
\text { per province }\end{array}$ & 1131 & 10 & 28.3321 & 45.8182 & 0.0000 & 271.0000 \\
\hline Number of years in office & 1131 & 10 & 2.9435 & 1.6953 & 1.0000 & 9.0000 \\
\hline $\begin{array}{l}\text { Capital expenditure per } \\
\text { capita in S/. million }\end{array}$ & 1131 & 10 & 0.0004 & 0.0008 & 0.0000 & 0.0254 \\
\hline Per capita MIP income in S/. million & 1131 & 10 & 0.0007 & 0.0021 & 0.0000 & 0.0944 \\
\hline $\begin{array}{l}\text { Mining canon per capita } \\
\text { in S/. million }\end{array}$ & 1131 & 10 & 0.0002 & 0.0013 & 0.0000 & 0.0470 \\
\hline Mining canon in S/. million & 1131 & 10 & 1.1613 & 8.5546 & 0.0000 & 476.9459 \\
\hline
\end{tabular}

Source: Prepared by the authors.

Table A3.2

Description of the sample for the political organizations model, 2002, 2006 and 2010

\begin{tabular}{lccrrrr}
\hline Variable & Districts & Years & \multicolumn{1}{c}{ Mean } & \multicolumn{1}{c}{$\begin{array}{l}\text { Standard } \\
\text { deviation }\end{array}$} & \multicolumn{1}{c}{ Minimum } & \multicolumn{1}{c}{ Maximum } \\
\hline Departmental illiteracy rate & 1131 & 3 & 0.1000 & 0.1000 & 0.0000 & 0.3000 \\
\hline Departmental poverty level & 1131 & 3 & 51.2000 & 19.8000 & 8.7000 & 88.7000 \\
\hline $\begin{array}{l}\text { Number of emergencies } \\
\text { per province }\end{array}$ & 1131 & 3 & 24.5000 & 43.2000 & 0.0000 & 271.0000 \\
\hline $\begin{array}{l}\text { Income under the modified } \\
\text { initial budget in S/. million }\end{array}$ & 1131 & 3 & 4.8000 & 16.3000 & 0.2000 & 431.1000 \\
\hline Mining canon in S/. million & 1131 & 3 & 0.9000 & 8.7000 & 0.0000 & 424.9000 \\
\hline Population & 1131 & 3 & 14704.4000 & 49909.6000 & 184.0000 & 983095.0000 \\
\hline
\end{tabular}

Source: Prepared by the authors.

Table A3.3

Description of the sample for the political organizations model, 2006 and 2010

\begin{tabular}{|c|c|c|c|c|c|c|}
\hline Variable & Districts & Years & Mean & $\begin{array}{l}\text { Standard } \\
\text { deviation }\end{array}$ & Minimum & Maximum \\
\hline Departmental illiteracy rate & 1131 & 2 & 0.1000 & 0.1000 & 0.0000 & 0.2000 \\
\hline Departmental poverty level & 1131 & 2 & 46.2000 & 19.9000 & 8.7000 & 88.7000 \\
\hline $\begin{array}{l}\text { Number of emergencies } \\
\text { per province }\end{array}$ & 1131 & 2 & 31.4000 & 49.5000 & 0.0000 & 271.0000 \\
\hline $\begin{array}{l}\text { Income under the modified } \\
\text { initial budget in S/. million }\end{array}$ & 1131 & 2 & 6.3000 & 19.3000 & 0.3000 & 431.1000 \\
\hline Mining canon in S/. million & 1131 & 2 & 1.4000 & 10.7000 & 0.0000 & 424.9000 \\
\hline Population & 1131 & 2 & 15126.2000 & 51910.5000 & 184.0000 & 983095.0000 \\
\hline
\end{tabular}

Source: Prepared by the authors. 